Article

\title{
Investigation of the Mechanical and Liquid Absorption Properties of a Rice Straw-Based Composite for Ayurvedic Treatment Tables
}

\author{
Abhishek Sadananda Madival ${ }^{1}$, Deepak Doreswamy ${ }^{2} * \mathbb{D}^{D}$, Shripathi Adiga Handady ${ }^{3}$, Krishna Raghava Hebbar ${ }^{3}$ \\ and Shobha Karabylu Lakshminarayana ${ }^{4}$ (D)
}

1 Department of Mechanical and Manufacturing Engineering, Manipal Institute of Technology, Manipal Academy of Higher Education, Manipal 576104, India; abhishek.madival@learner.manipal.edu

2 Department of Mechatronics Engineering, Manipal Institute of Technology, Manipal Academy of Higher Education, Manipal 576104, India

3 Division of Ayurveda, Center for Integrative Medicine and Research, Manipal Academy of Higher Education, Manipal 576104, India; shripathi.adiga@manipal.edu (S.A.H.); kr.hebbar@manipal.edu (K.R.H.)

4 Department of Microbiology, Melaka Manipal Medical College, Manipal Academy of Higher Education, Manipal 576104, India; shobha.kl@manipal.edu

* Correspondence: deepak.d@manipal.edu; Tel.: +91-984-463-3124

check for

updates

Citation: Madival, A.S.; Doreswamy,

D.; Handady, S.A.; Hebbar, K.R.;

Lakshminarayana, S.K. Investigation

of the Mechanical and Liquid

Absorption Properties of a Rice

Straw-Based Composite for

Ayurvedic Treatment Tables.

Materials 2022, 15, 606. https://

doi.org/10.3390/ma15020606

Academic Editor: Grzegorz Lesiuk

Received: 4 December 2021

Accepted: 28 December 2021

Published: 14 January 2022

Publisher's Note: MDPI stays neutral with regard to jurisdictional claims in published maps and institutional affiliations.

Copyright: (c) 2022 by the authors. Licensee MDPI, Basel, Switzerland. This article is an open access article distributed under the terms and conditions of the Creative Commons Attribution (CC BY) license (https:// creativecommons.org/licenses/by/ $4.0 /)$.

\begin{abstract}
Managing rice crop stubble is one of the major challenges witnessed in the agricultural sector. This work attempts to investigate the physical, mechanical, and liquid absorption properties of rice straw (RS)-reinforced polymer composite for assessing its suitability to use as an ayurvedic treatment table. This material is expected to be an alternative for wooden-based ayurvedic treatment tables. The results showed that the addition of rice straw particles $\left(\mathrm{RS}_{\mathrm{p}}\right)$ up to $60 \%$ volume in epoxy reduced the density of the composite material by $46.20 \%$ and the hardness by $15.69 \%$. The maximum tensile and flexural strength of the $\mathrm{RS}_{\mathrm{p}}$ composite was $17.53 \mathrm{MPa}$ and $43.23 \mathrm{MPa}$, respectively. The scanning electron microscopy (SEM) analysis showed deposits of silica in the form of phytoliths in various size and shapes on the outer surface of RS. The study also revealed that the water absorption rate (WA) was less than $7.8 \%$ for the test samples with $45 \%$ volume of $\mathrm{RS}_{\mathrm{p}}$. Interestingly the test samples showed greater resistance to the absorption of Kottakal Dhanvantaram Thailam $(<2 \%)$. In addition, the developed samples showed resistance towards bacterial and fungal growth under the exposure of treatment oils and water.
\end{abstract}

Keywords: natural composite; rice straw; ayurvedic treatment table; microbial study; tensile strength

\section{Introduction}

In the recent years, there has been a growing interest to develop sustainable and eco-friendly materials for a variety of applications using the waste generated from various sources. The agricultural sector produces organic waste from different crops such as cereals, sugarcane, coconut, and live stocks, etc. Rice is one of the majorly harvested crops, and rice husk ( $\mathrm{RH})$ and $\mathrm{RS}$ are the by-products of the rice crop. In India, $352 \mathrm{Mt}$ of agricultural stubble waste is produced annually by harvesting of rice/paddy, wheat, barley, and maize [1,2]. The majority of these wastes are unutilized and are discarded by burning and dumping in open environment. The RS/RH have intrinsic properties such as a high calorific power (about $4000 \mathrm{kcal} / \mathrm{kg}$ ), low thermal coefficient, hardness, fibrousness, and abrasive nature. They find applications as building panels for brake pads, thermal and acoustic insulation, etc., [3-10]. The RH is also used as biomass fuel for industrial and domestic heating purposes [11], but it creates a new residue in the form of ash composed of silica (ranging from $80 \%$ to $95 \%$ ). The ash is resistant to chemical etching (acid slag) and thermal shocks (above $600{ }^{\circ} \mathrm{C}$ ) and has low thermal conductivity and low mechanical properties, making it suitable for producing ceramic material. In addition, it 
also finds an application as insulating material for cold storage, floors, walls, and roofs. The thermal conductivity of RH ranges from $0.064-0.093 \mathrm{~W} / \mathrm{M}^{2}$ [12]. Several researchers have explored the potential of RS in polymers for different applications. RS-reinforced epoxy particle boards showed improved tensile strength $\left(\sigma_{T}: 0.60 \mathrm{kgf} / \mathrm{mm}^{2}\right)$ [13]. Small-sized $\mathrm{RS}_{\mathrm{p}}$ boards showed higher moisture resistance compared to larger-sized particles. Automotive bumpers developed using $\mathrm{RS}_{\mathrm{p}}$ showed $16.83 \%$ higher $\sigma_{T}$ compared to standard bumper materials [14]. A 3-D printed composite using RS powder and poly-lactic acid improved the $\sigma_{T}-44.66 \mathrm{MPa}$ and flexural strength $\left(\sigma_{F}\right)-76.06 \mathrm{MPa}$ [15]. Reinforcement of RS with polypropylene showed maximum $\sigma_{T}-7.04 \mathrm{MP}$ and $\sigma_{F}-40.71 \mathrm{MPa}$ [16]. Results also indicated an improvement in the modulus of the composite due to the addition of RS. The RSreinforced polyethylene composite showed maximum $\sigma_{T}(18.2 \mathrm{MPa})$ and $\sigma_{F}(24.5 \mathrm{MPa})$ [17]. Studies showed that the use of agro-wastes improved the wear properties of the polymer composites, which make them suitable for brake pad applications [18-20].

The literature shows that the RS can be effectively used for thermal insulation, brake pads, and automotive bumper application. However, the tensile and flexural properties of RS-based polymer composites are low compared to other natural and synthetic fiberreinforced composites. RS being an organic material finds extensive scope for producing bio/semi-bio composites for structural applications involving lower loads. Recently, health treatments by Ayurveda principles are becoming more attractive, particularly stress management and physiotherapy [21-24]. Ayurveda provides a wide range of treatment for certain diseases through procedural interventions such as Shastrapranidana, Bahirparimarjana, and Antarparimarjana chikitsa. The external therapies include simple oil massages and various sudation therapies [25]. Internal purification therapies are combined with external therapies such as massage, steam, etc., which are done on specially designed treatment tables with the following dimensions: length 4 Hasthas, 1 Hastha wide, and $\frac{1}{4}$ Hastha in height [Dharakalpa]. These tables are made using wood of plant species, namely, Plaksha, Udumbara, Gandhasara, Nyagrodha, Devadruma, Punnaga, Kapitha, Chocha, Bakula Ashoka, Asana, Amra, Arjuna, Agnimantha, Amogha, Khadira, Nimba, Bilwa, Champaka, Dola, etc. [26,27]. Although wood is an ideal material for this application in the era of deforestation, the availability of quality wood, its cost, and its maintenance are great challenges [28]. In this view, synthetic materials such as polyvinyl chloride and polyurethane combined with glass fiber fabric are used in the making of therapeutic tables. Such reinforcement may cause fiber glass dermatitis, which includes symptoms such as redness of the affected skin, itching, fissure of skin, etc. The extent to which it may affect a person depends on the duration of exposure, the depth of penetration into the skin, and environmental factors such as humidity, temperature, etc. With the growing consciousness regarding this issue among the public, patients prefer to use organic materials for their treatment. Hence, wood-based equipment or that which contains organic materials as major components is gaining popularity compared to synthetic-based materials. In this view, the present work investigates the mechanical and liquid absorption properties of RS-based composites for Ayurvedic therapy tables. The results obtained from this work are promising from the following viewpoints. The $\mathrm{RS}_{\mathrm{p}}$ composite exhibits the requisite properties suitable for making eco-friendlier ayurvedic treatment tables. In addition to this, the use of RS provides a sustainable solution for the replacement of synthetic fibers for certain applications. This has direct societal and environmental implications by generating additional revenue to the paddy growers, which directly addresses the solution to problems associated with disposal of agro-waste generated from the harvesting of RS.

\section{Materials and Methods}

\subsection{Materials}

Epoxy resin (Lapox L12) and hardener (K6) were used for the preparation of the test samples and were procured from Atul Pvt. Ltd., Gujarat, India. The pot life of epoxy and hardener mixture is 30-40 min, and the curing time is between $14 \mathrm{~h}$ to $24 \mathrm{~h}$ at a standard temperature of $25^{\circ} \mathrm{C}$. The properties of the epoxy and hardener material used are shown 
in Table 1. The RS used for the fabrication was collected from agricultural fields in Udupi, India. The RS was segregated and washed with distilled water to remove the residual content and then dried in an oven at a temperature of $80^{\circ} \mathrm{C}$. The RS was then slit along the straw direction and was chopped into particles with a size less than $2 \mathrm{~mm}$ and then ground to produce fine $\mathrm{RS}_{\mathrm{p}}$. Figure 1 details the stages of $\mathrm{RS}_{\mathrm{p}}$ preparation.

Table 1. Properties of epoxy (As specified by the supplier).

\begin{tabular}{cc}
\hline Properties & Range \\
\hline Density of epoxy (L-12) at $25^{\circ} \mathrm{C}$ & $1.1-1.2 \mathrm{~g} / \mathrm{cm}^{3}$ \\
Density of hardener (K-6) at $25^{\circ} \mathrm{C}$ & $0.95-1.1 \mathrm{~g} / \mathrm{cm}^{3}$ \\
Tensile strength & $55-70 \mathrm{MPa}$ \\
Flexural strength & $120-140 \mathrm{MPa}$ \\
Impact strength & $17-20 \mathrm{KJ} / \mathrm{m}^{2}$ \\
Thermal conductivity & $0.211 \mathrm{kCal} / \mathrm{m} \mathrm{h}^{\circ} \mathrm{C}$ \\
Co-efficient of thermal expansion & $64-68 \times 10^{-6} /{ }^{\circ} \mathrm{C}$ \\
Water absorption $\left(25^{\circ} \mathrm{C} / 24 \mathrm{~h}\right)$ & $0.5 w / w \%(\mathrm{Max})$ \\
\hline
\end{tabular}

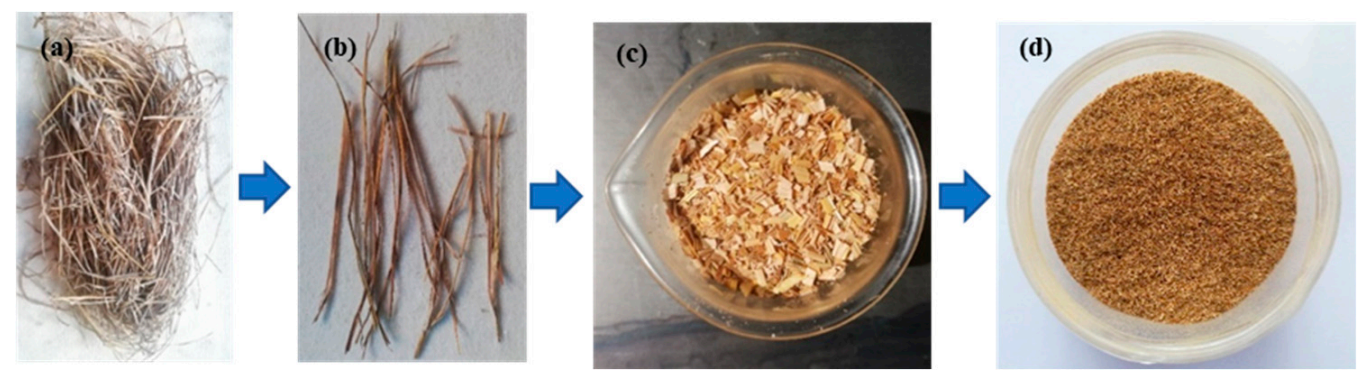

Figure 1. Preparation of RS particles (a) Bale, (b) Segregation, (c) Particles and (d) Fine RS particles.

\subsection{Preparation of RSp-Reinforced Composite}

The hand layup method was used to fabricate the $\mathrm{RS}_{\mathrm{p}}$ test samples [29-31]. Table 2 shows details of different test samples prepared by varying the volume fraction $\left(V_{F}\right)$ of $R_{p}$. The mold cavity was coated with polyvinyl alcohol-releasing agent to easily remove test samples from the mold. The RS particles were mixed with epoxy to form a uniform matrix mixture, and then the hardener was added at a ratio of 1:10. This homogenous mixture was poured into the mold cavity, and a brush was used to uniformly spread the mixture throughout the mold cavity to achieve a homogeneous structure. A metal plate whose surface was coated with releasing agent was placed on the mold to apply uniform pressure on top of the mold cavity. The laminate was cured at atmospheric temperature for $24 \mathrm{~h}$ and post cured at $80^{\circ} \mathrm{C}$ for $30 \mathrm{~min}$ in a furnace. Figure 2 shows the distribution of $\mathrm{RS}_{\mathrm{p}}$ in the composite.

Table 2. Composition and coding of test samples.

\begin{tabular}{cccc}
\hline S1. No & Sample Code & $\mathbf{R S}_{\mathbf{p}}\left(\mathbf{V}_{\mathbf{f}}\right)$ & Epoxy $\left(\mathbf{V}_{\mathbf{m}}\right)$ \\
\hline 1 & Neat & 0 & 1 \\
2 & R15E85 & 0.15 & 0.85 \\
3 & R30E70 & 0.30 & 0.70 \\
4 & R45E55 & 0.45 & 0.55 \\
5 & R60E40 & 0.60 & 0.40 \\
\hline
\end{tabular}



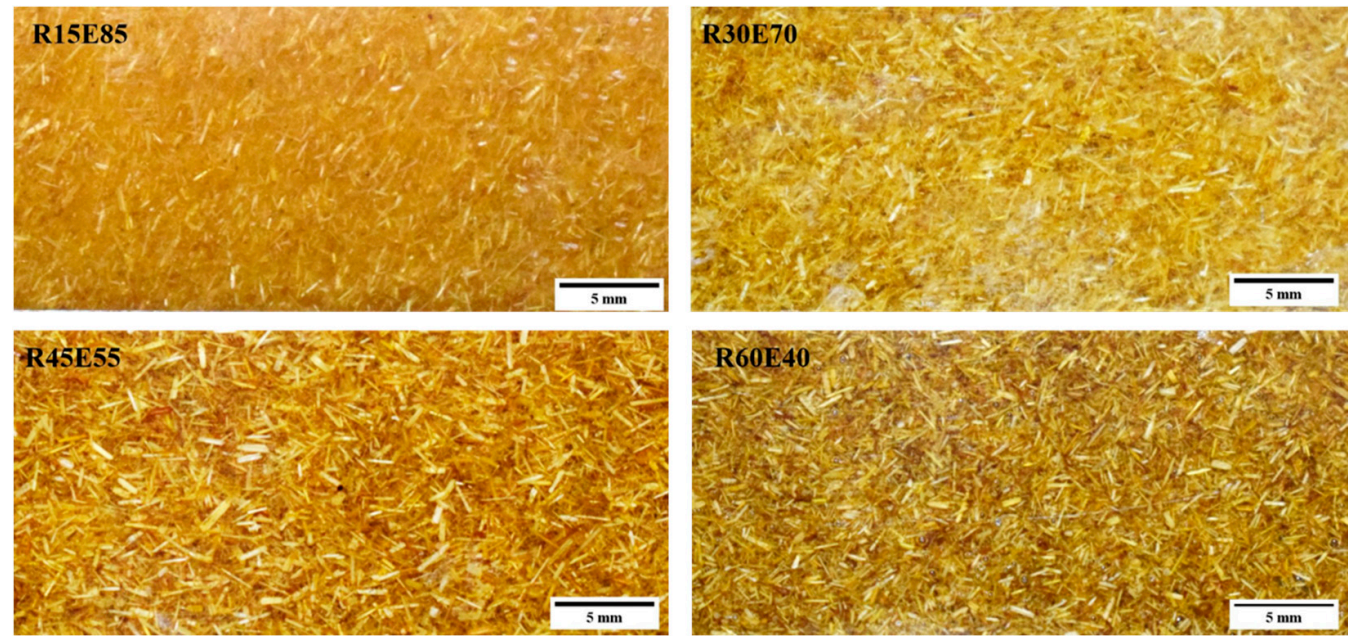

Figure 2. $\mathrm{RS}_{\mathrm{p}}$-reinforced test samples.

\subsection{Physical and Mechanical Properties}

\subsubsection{Density and Void Content}

The experimental density $\left(\rho_{c e}\right)$ of the test samples was evaluated by Archimedes' principle. A test sample of known weight was immersed in a flask filled with distilled water, and the water displaced by the test sample was measured. The average $\rho_{c e}$ of the test sample was calculated based on the result of 10 trials. The theoretical density $\left(\rho_{c t}\right)$ of the $\mathrm{RS}_{p}$ composites was calculated based on Equation (1). The void content $\left(V_{c}\right)$ in the test samples was calculated by considering the $\rho_{c e}$ and $\rho_{c e}$ of the composite using Equation (2), where $\rho_{m, f}$ and $V_{m, f}$ are the density and volume fraction of matrix and fiber material, respectively $[32,33]$.

$$
\begin{gathered}
\rho_{c t}=\rho_{m} V_{m}+\rho_{f} V_{f} \\
V_{c}=\frac{\rho_{c t}-\rho_{c e}}{\rho_{c t}} \times 100
\end{gathered}
$$

\subsubsection{Microhardness}

The microhardness test of the prepared $\mathrm{RS}_{\mathrm{p}}$ composites was evaluated by a Vickers hardness tester (Make: MMT-X, Matsuzawa Co., Ltd., Toshima, Akita, Japan) [34]. Using a diamond indenter, a load of $100 \mathrm{~g}$ was applied to the test sample for a dwell period of $10 \mathrm{~s}$ to produce the indentation on the surface of the specimen $(50 \mathrm{~mm} \times 25 \mathrm{~mm} \times 3 \mathrm{~mm})$. The diagonal lengths of the indented region on the test sample surface were measured using a microscope. The Vickers hardness number $\left(V_{h}\right)$ was calculated using Equation (3), where $F_{a}$ is the applied forced and $A_{i}$ is the indentation area. The measurements were repeated for five trials on different indentation locations on the test sample.

$$
V_{h}=1.854 \frac{F_{a}}{A_{i}{ }^{2}}
$$

\subsubsection{Tensile Strength of the RS and $\mathrm{RS}_{\mathrm{p}}$ Composite}

The $\sigma_{T}$ of the RS fiber was evaluated as per the ASTM C1557-20 standard. The RS fibers were split into quarters along the fiber direction to form a single fiber strand. A mounting tab was used to load the RS fiber into the testing machine. The ends of the RS fiber with a fiber gauge length of $50 \mathrm{~mm}$ were glued using adhesive (epoxy). Figure 3a shows the mounting tab with the RS fiber. As shown in Figure $3 b$, the mounting tab was placed in the grips of the testing machine (Make: WANCE ETM-A, Shenzen WANCE testing machine Co., Ltd., Beijing, China), and the sides of the mounting tab were cut to release the support of the cardboard structure without damaging the RS. The test was carried out by maintaining a cross-head speed of $0.2 \mathrm{~mm} / \mathrm{min}$ until the fiber failed. The $\sigma_{T}$ of the 
RS fiber was calculated using Equation (4), where $F_{m}$ is the maximum force and $A_{f}$ is the cross-sectional area of the fiber.

$$
\sigma_{T}=\frac{F_{m}}{A_{f}}
$$
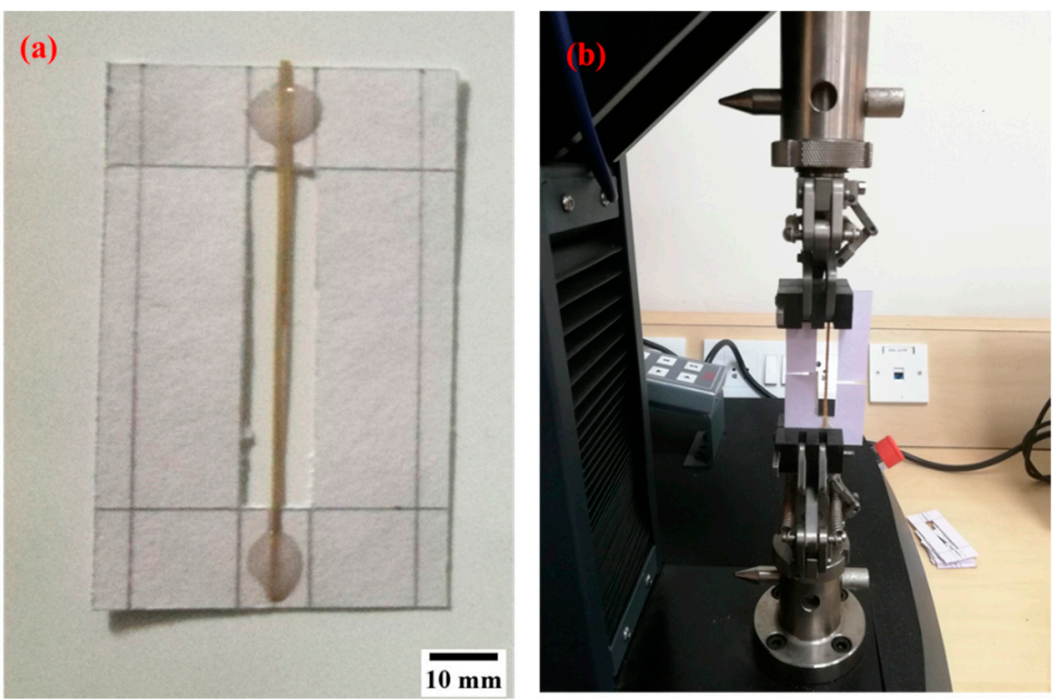

Figure 3. Tensile test of the RS fiber. (a) RS test sample; (b) Testing instrument.

The $\sigma_{T}$ and $\sigma_{F}$ of the test samples was evaluated using a universal testing machine (Make: UNITEK 9940, Fuel Instruments and Engineers Pvt. Ltd., Kolhapur, Maharastra, India). The $\sigma_{T}$ and $\sigma_{F}$ of the test samples was evaluated as per the ASTM D 3039 and ASTM D790 standards, respectively. A cross-head speed of $2 \mathrm{~mm} / \mathrm{min}$ was maintained during the test. The maximum failure load of the test samples was recorded, and $\sigma_{T}$ and $\sigma_{F}$ were calculated using Equations (5) and (6), respectively, where $A_{c}, L, w$, and $d$ are the crosssectional area $\left(\mathrm{mm}^{2}\right)$, length $(\mathrm{mm})$, width $(\mathrm{mm})$, and thickness $(\mathrm{mm})$, respectively [35-37].

$$
\begin{gathered}
\sigma_{T}=\frac{F_{m}}{A_{c}} \\
\sigma_{F}=\frac{3 F_{m} L}{2 w d^{2}}
\end{gathered}
$$

\subsubsection{Liquid Absorption and Microbial Study}

The liquid absorption rate $\left(L_{a}\right)$ of the test samples was evaluated as per the ASTM D570-98 standards by immersing the tests samples in water and Kottakal Dhanvantaram Thailam oil (KDT). Test samples with $50 \mathrm{~mm} \times 2.5 \mathrm{~mm} \times 3 \mathrm{~mm}$ dimensions were prepared for the liquid absorption test. The initial weights of the test samples were recorded and then immersed in normal tap water and KDT oil individually. The weight of each test sample was measured at regular intervals of $24 \mathrm{~h}$ after immersion. The water and oil absorption rate of the specimens was calculated by using Equation (7), where $W_{1}$ and $W_{2}$ are the initial and final weight (g) of the test samples. Further, the formation and growth of microorganisms in the prepared test samples under the influence of moisture and KDT oil were evaluated by conducting a microbial study. The test samples were continuously immersed in KDT oil and bacterial suspension solution for 15 days, and the attachment of microorganisms on the $\mathrm{RS}_{\mathrm{p}}$ test samples was studied $[38,39]$.

$$
L_{a}=\frac{W_{2}-W_{1}}{W_{2}} \times 100
$$




\section{Results}

\subsection{Morphological Study of Rice Straw}

The morphological features of untreated RS were examined using a SEM (Make: EVO MA18, Carl Zeiss Ltd., Cambridge, UK). The structure of the inner and outer surfaces of untreated RS was examined by splitting the RS along its axis. Figure $4 a-d$ shows the SEM images at different locations of the outer and inner surfaces of RS. The outer surface of RS shows large globular and small spiked symmetrically arranged grid-like structures of phytoliths $[40,41]$. These phytoliths occurred in different shape and size throughout the RS surface [42]. These structures were covered by a silica layer and are responsible for the hydrophobic nature of RS $[43,44]$. The variation in the surface roughness between the inner and outer surfaces of the RS was clearly visible in the SEM images. The comparison of their images shows that the inner surface of RS appeared to be smoother compared to its outer surface.
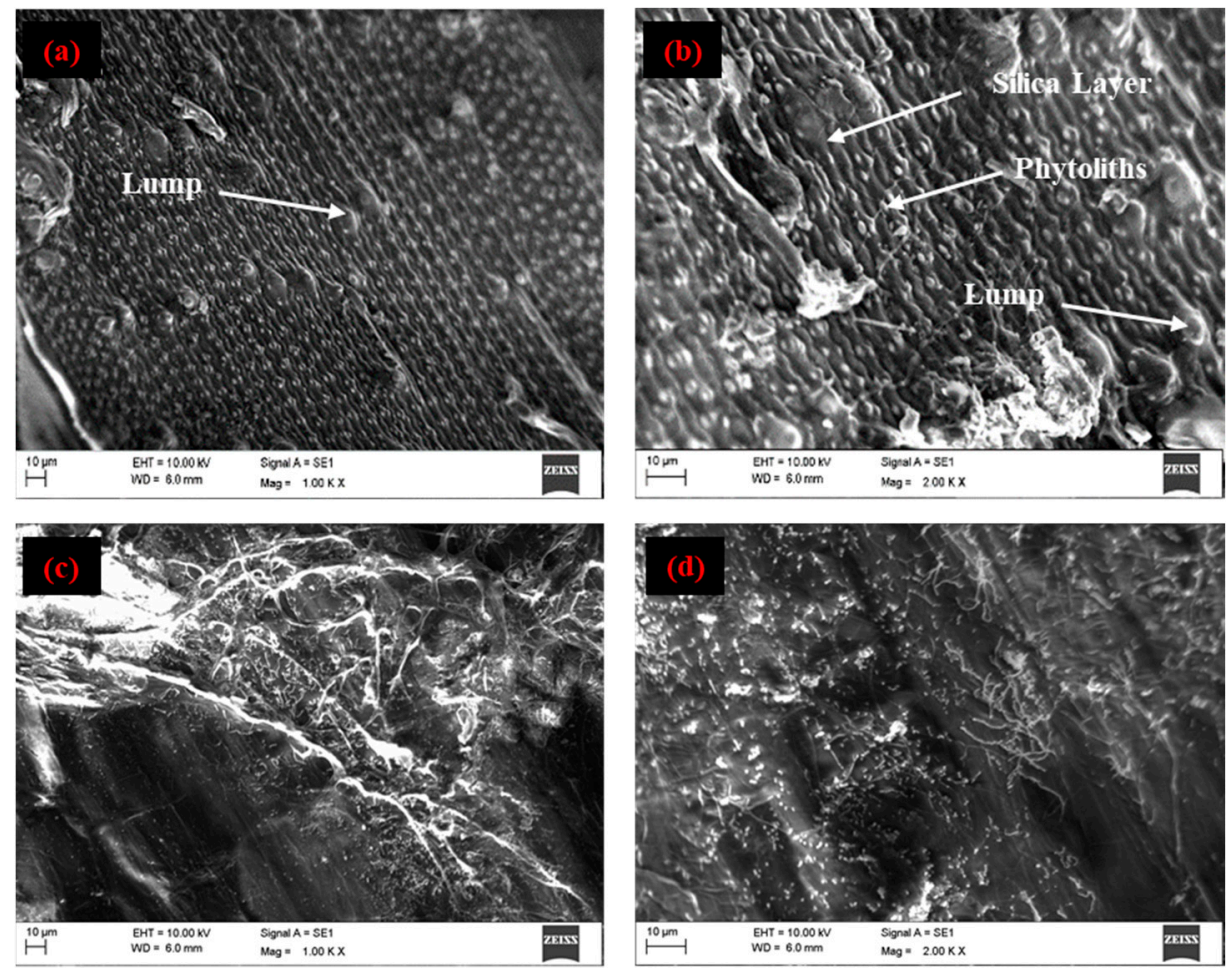

Figure 4. Microscopic view. (a,b) outer surface and (c,d) inner surface of RS.

\subsection{Density}

The average density of $\mathrm{RS}_{\mathrm{p}}$ was $0.27 \pm 0.013 \mathrm{~g} / \mathrm{cm}^{3}$. The $\rho_{c t}$ and $\rho_{c e}$ of the test samples are shown in Figure 5. It is seen that the density of the test samples decreased with an increase in the RS content in the epoxy. The $\rho_{c e}$ of R15E85, R30E70, R45E55, and R60E40 composites was reduced by $14.44 \%, 29.89 \%, 42.39 \%$, and $54.86 \%$, respectively compared with neat epoxy composite. This reduction in the density of $\mathrm{RS}_{\mathrm{p}}$ composites is mainly due to the lower density of $\mathrm{RS}_{\mathrm{p}}$ compared to the epoxy material. It was also observed that the $\rho_{c e}$ of the test samples was lower than $\rho_{c t}$. This is primarily due to the presence of small voids that are formed during the fabrication of test samples. Complete elimination of such voids is unavoidable, and they are generated due to the entrapment of gases generated from the chemical reaction between the epoxy and hardener during the fabrication process $[45,46]$. It was observed that the void content in test samples increased with increased $\mathrm{RS}_{\mathrm{p}}$ in epoxy due to the increased agglomerations at higher $\mathrm{RS}_{\mathrm{p}}$ concentrations. These agglomerated zones prevented the escape of gases and produced voids of varied size (94 $\mu \mathrm{m}$ to $676 \mu \mathrm{m})$ in the test sample, as observed in Figure 6. 


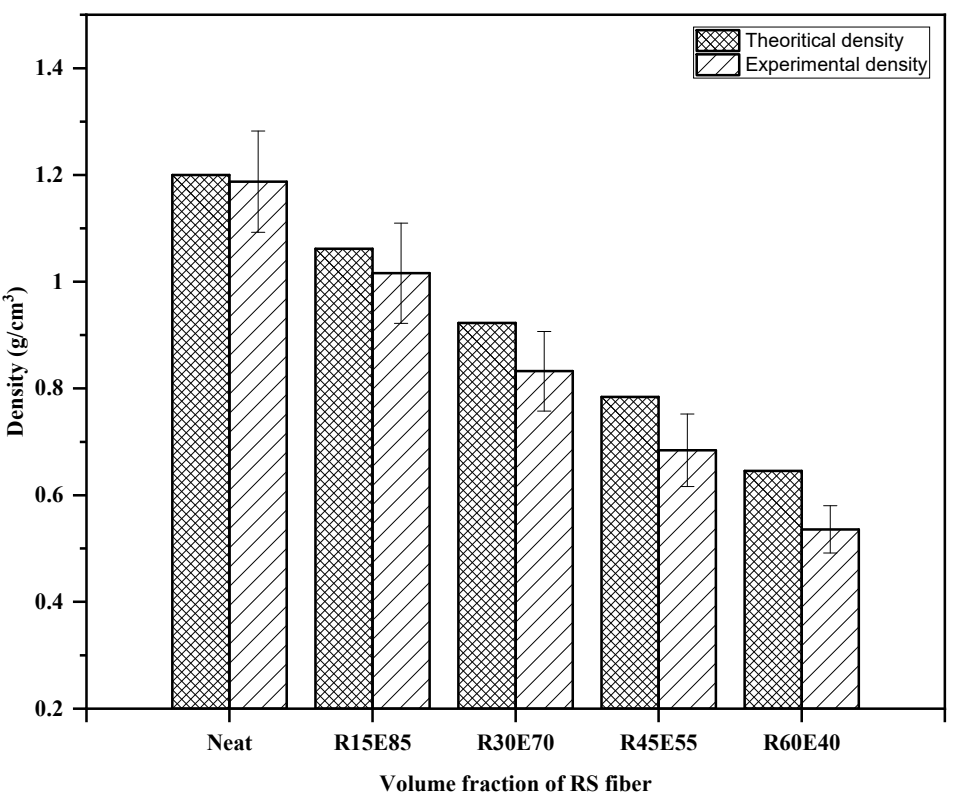

Figure 5. Density of composites.
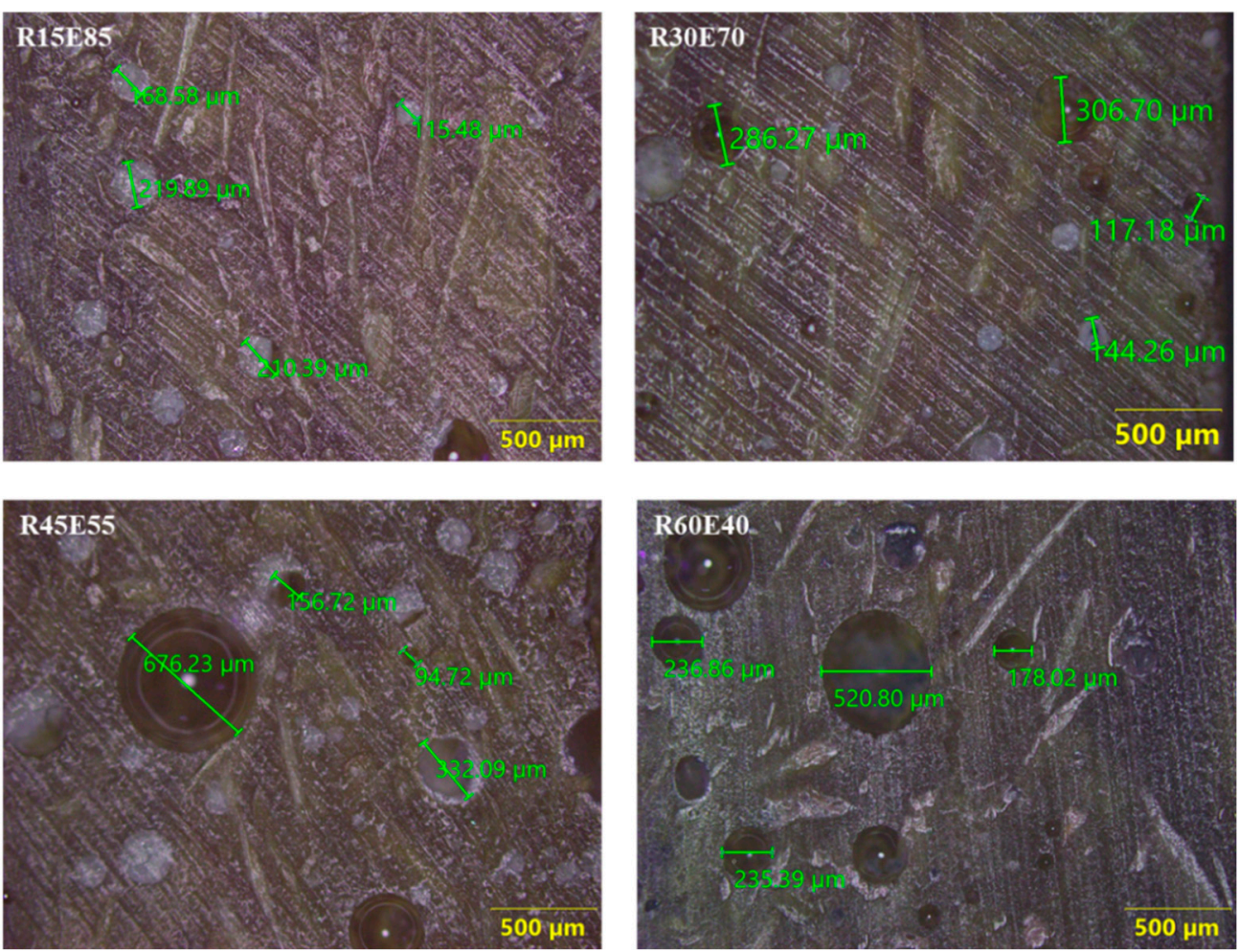

Figure 6. Optical microscope images of voids in the test samples.

\subsection{Microhardness}

Figure 7 shows the surface hardness values of the test samples. The neat epoxy had the highest hardness $(21.1 \mathrm{HV})$. It was observed that the surface hardness of the $\mathrm{RS}_{\mathrm{p}}$ test samples decreased with an increase in the $\mathrm{RS}_{\mathrm{p}}$ content compared to the hardness of the neat epoxy test sample. This is due to the soft nature of $\mathrm{RS}_{\mathrm{p}}$ reinforcement embedded in the epoxy matrix. The load applied to the surface of the test samples was effectively absorbed by the soft $\mathrm{RS}_{\mathrm{p}}$. Such an interaction between the $\mathrm{RS}_{\mathrm{p}}$ and epoxy material [47] led to a marginal reduction in the hardness of the test samples with a higher $\mathrm{RS}_{\mathrm{p}}$ content. 


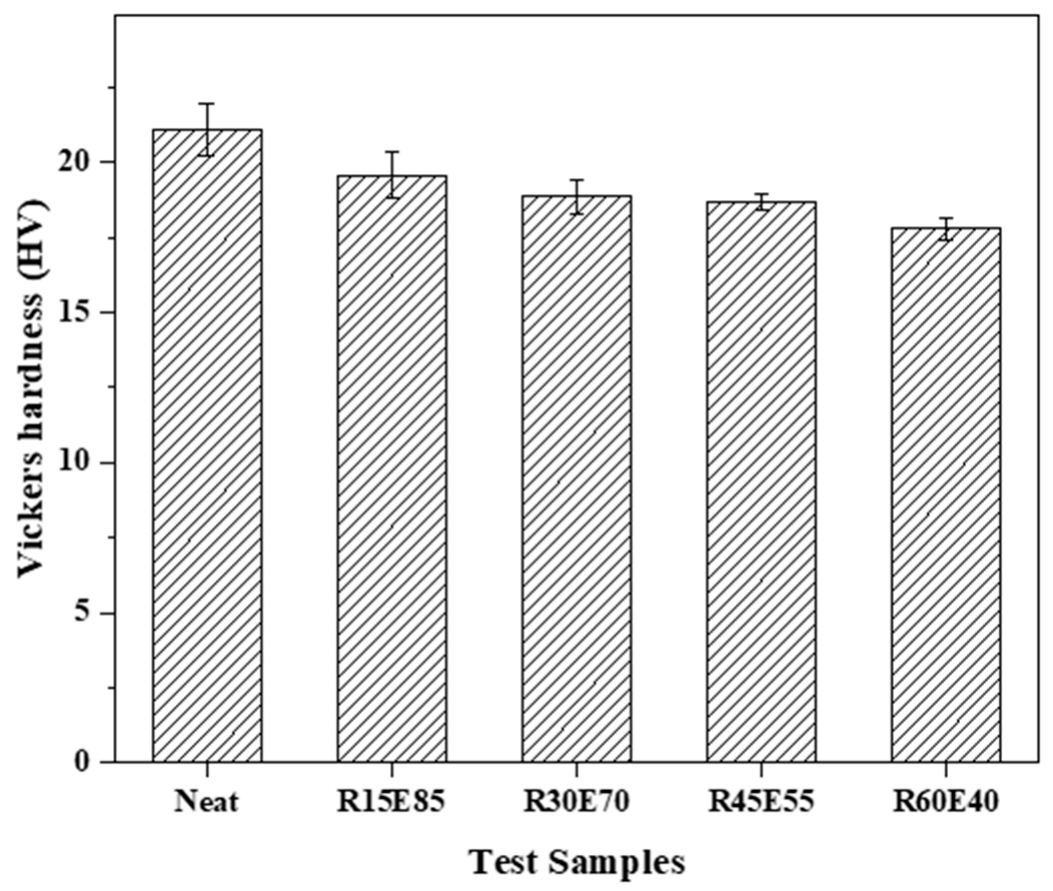

Figure 7. Vickers hardness of test samples.

\subsection{Tensile Properties}

The average $\sigma_{T}$ of RS fiber based on five experimental trials was calculated to be 180.04 MPa. Figure 8 shows the $\sigma_{T}$ of the test samples.

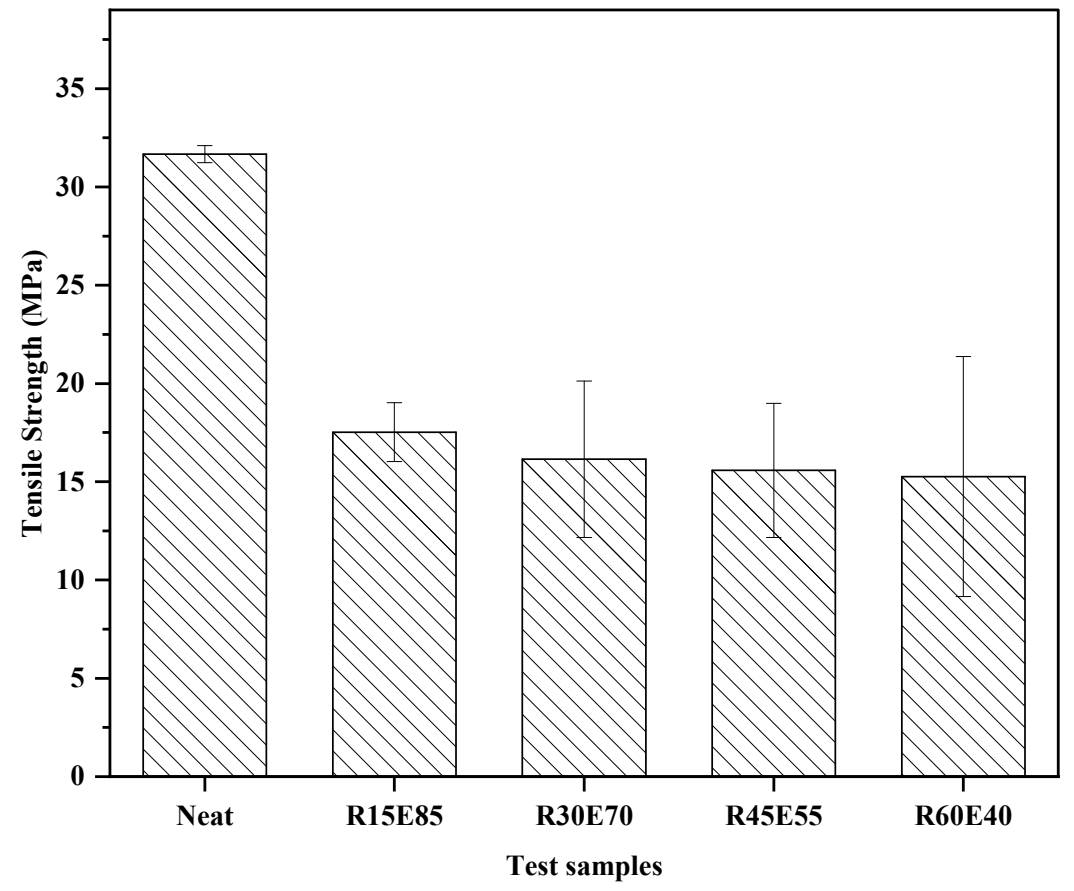

Figure 8. Tensile strength of the test samples.

The neat epoxy had the highest $\sigma_{T}(31.67 \mathrm{MPa})$ compared to R15E85, R30E70, R45E55, and R60E40. The $\sigma_{T}$ of the composite decreased with an increase in the $\mathrm{RS}_{\mathrm{p}}$ content. The $\sigma_{T}$ was reduced by $12.89 \%$ by increasing the $\mathrm{RS}_{\mathrm{p}}$ content from $\mathrm{V}_{\mathrm{F}}: 0.15$ to $\mathrm{V}_{\mathrm{F}}: 0.60$ This was due to the randomly oriented discontinuous reinforcement phase in the matrix. As discussed earlier, the $\mathrm{RS}_{\mathrm{p}}$ agglomeration and void content increased with an increase 
in the $\mathrm{RS}_{\mathrm{p}}$ content. The combined effect of the above and the weak interfacial bonding between the $\mathrm{RS}_{\mathrm{p}}$ and epoxy material resulted in the poor transfer of the load from the matrix phase to the reinforcement phase. Hence, the $\sigma_{T}$ of the $\mathrm{RS}_{\mathrm{p}}$ test samples decreased compared to neat epoxy. The higher deviation in the $\sigma_{T}$ values of the test samples at a higher $\mathrm{RS}_{\mathrm{p}}$ content indicated structural inhomogeneity in the test samples. Similar trends were also observed in studies conducted on the tensile properties of natural fiber-reinforced polymer composites $[48,49]$.

Figure 9 shows the stress-strain plot of test samples under a tensile load. The neat epoxy composite had higher strength compared to R15E85, R30E70, R45E55, and R60E40. The strain rate was higher for the neat epoxy composite. The strength of the composites was found to vary marginally with an increase in the $\mathrm{RS}_{\mathrm{p}}$ content. It is well known that the load applied is transferred to the $\mathrm{RS}_{\mathrm{p}}$, and the corresponding location acts as a stressconcentration region. There was a non-uniform stress distribution in the test samples, and the maximum stresses were observed near the reinforcement. Due to the applied load, the epoxy matrix near the filler interface broke due to higher stresses, leading to a decrease in the tensile strength of the $\mathrm{RS}_{\mathrm{p}}$ composite materials. The non-uniformity in the distribution of the stress-concentrated location will increase with an increase in the $\mathrm{RS}_{p}$ concentration. Hence, the tensile strength of the composite decreased with an increase in the $\mathrm{RS}_{\mathrm{p}}$ content. It is also seen from the figure that there was a gain of strain with the increase in the $\mathrm{RS}_{\mathrm{p}}$ content (0.015-0.02).

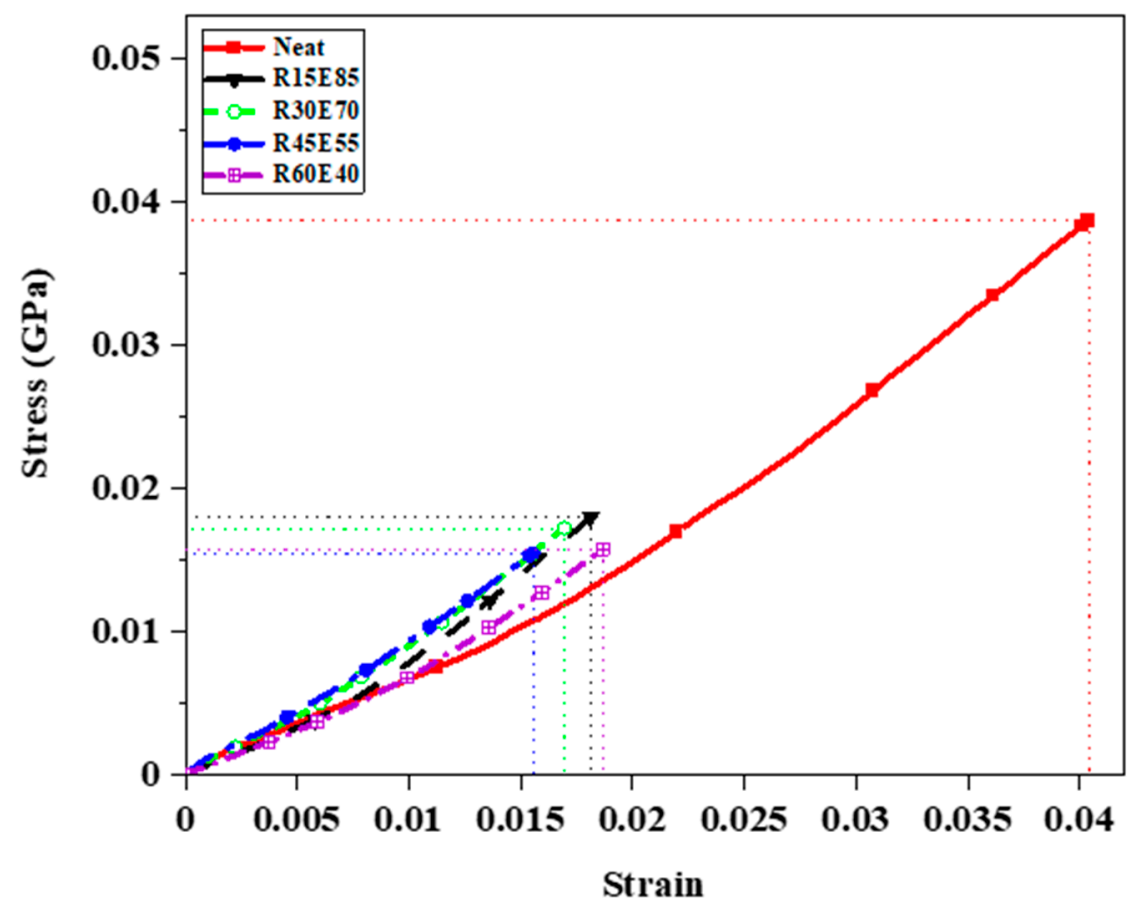

Figure 9. Stress-strain plot of test samples under a tensile load.

\subsection{Flexural Properties}

Figure 10 shows the $\sigma_{F}$ of the test specimens. The neat composite showed a maximum $\sigma_{F}(107.6 \mathrm{MPa})$ compared to the $\mathrm{RS}_{\mathrm{p}}$ composites. The $\sigma_{F}$ increased with an increase in $\mathrm{RS}_{\mathrm{p}}$ up to $\mathrm{RS}_{\mathrm{p}} \mathrm{V}_{\mathrm{F}}$ : 0.45 , and thereafter, a decreasing trend was observed. The load applied during the flexural test acted in the direction perpendicular to the $\mathrm{RS}_{\mathrm{p}}$ surface. It is inferred from the results that the applied load was completely absorbed up to a critical volume of $\mathrm{RS}_{\mathrm{p}}\left(\mathrm{V}_{\mathrm{F}}: 0.45\right)$. Loading beyond this concentration resulted in decreasing trend of $\sigma_{F}$. This was attributed due to the formation of voids and agglomerations particularly at higher particle concentrations, which affects the structural integrity of the material [50,51]. 


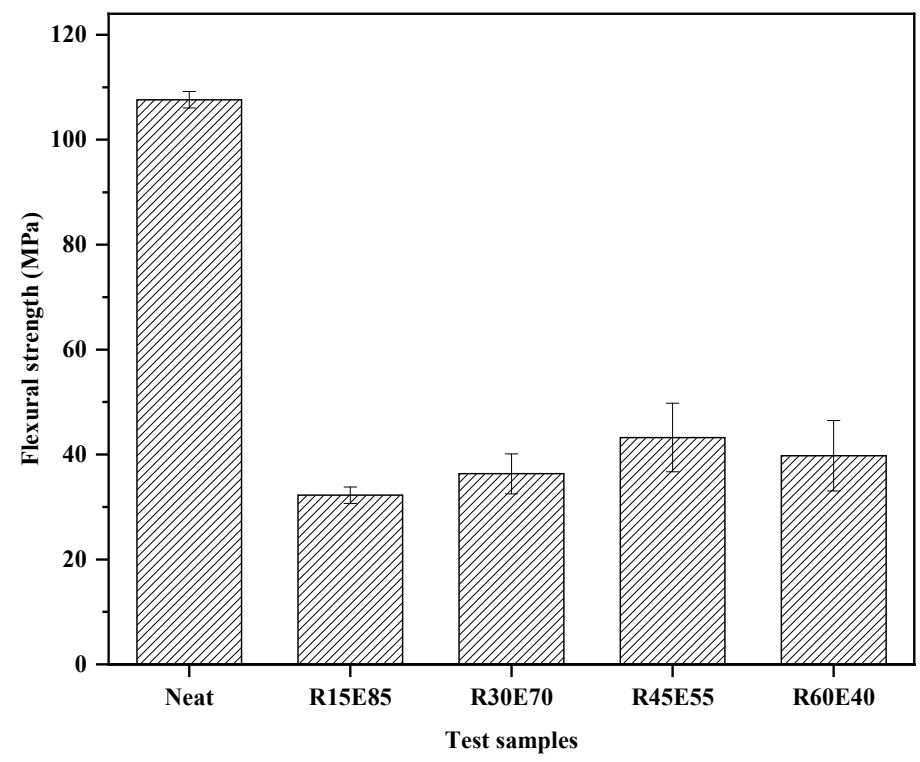

Figure 10. Flexural strength of test samples.

Figure 11 shows the stress-strain plot of test samples under a flexural load. The neat composite showed higher stress and strain compared to the $\mathrm{RS}_{\mathrm{p}}$ test samples. A higher concentration of $R S_{p}$ in epoxy was observed to reduce the strength of the $R_{p}$ test samples. The higher reinforcement in epoxy resulted in poor wettability of $\mathrm{RS}_{\mathrm{p}}$ and thus reduced the internal bond strength of the composite. The discontinuous phase of $\mathrm{RS}_{\mathrm{p}}$ failed to completely absorb the stress generated during the test. It was observed from the figure that higher $\mathrm{RS}_{\mathrm{p}}$ in epoxy increased the strain in the $\mathrm{RS}_{\mathrm{p}}$ test samples. A maximum strain of 0.015 was observed for the R60E40 test sample amongst the $\mathrm{RS}_{\mathrm{p}}$-reinforced test samples.

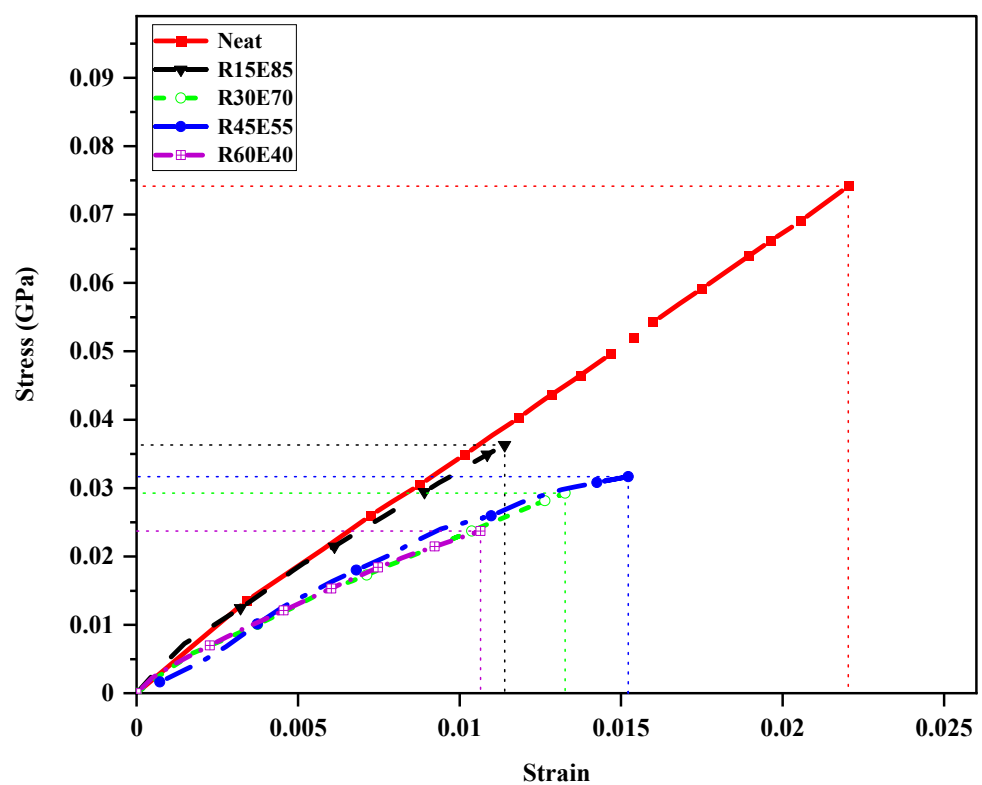

Figure 11. Stress-strain plot of test samples under a flexural load.

\subsection{Fractural Analysis of Tensile and Flexural Test-Failed Specimens}

Figure 12a,b shows the fractured surfaces of tensile and flexural test samples, respectively. It is seen that due to the tensile load, the specimens were split at the center of the gauge length. The microscopic observation shows that there were no delamination-related damages on the gripping tab region as well as on other surfaces. The failure of the material occurred at the center of the gauge length, and the fracture line was aligned almost hori- 
zontally across the specimens. Figures 13 and 14 show the optical images of the fractured surfaces of test samples subjected to tensile and flexural tests, respectively. The fractured surfaces show that there were no fiber pull-outs from the matrix and damages near the tab section, which indicated the good structural integrity between the $\mathrm{RS}_{\mathrm{p}}$ and matrix material. Fractured surfaces of test samples showed the presence of voids formed by the entrapment of gases during the curing process.
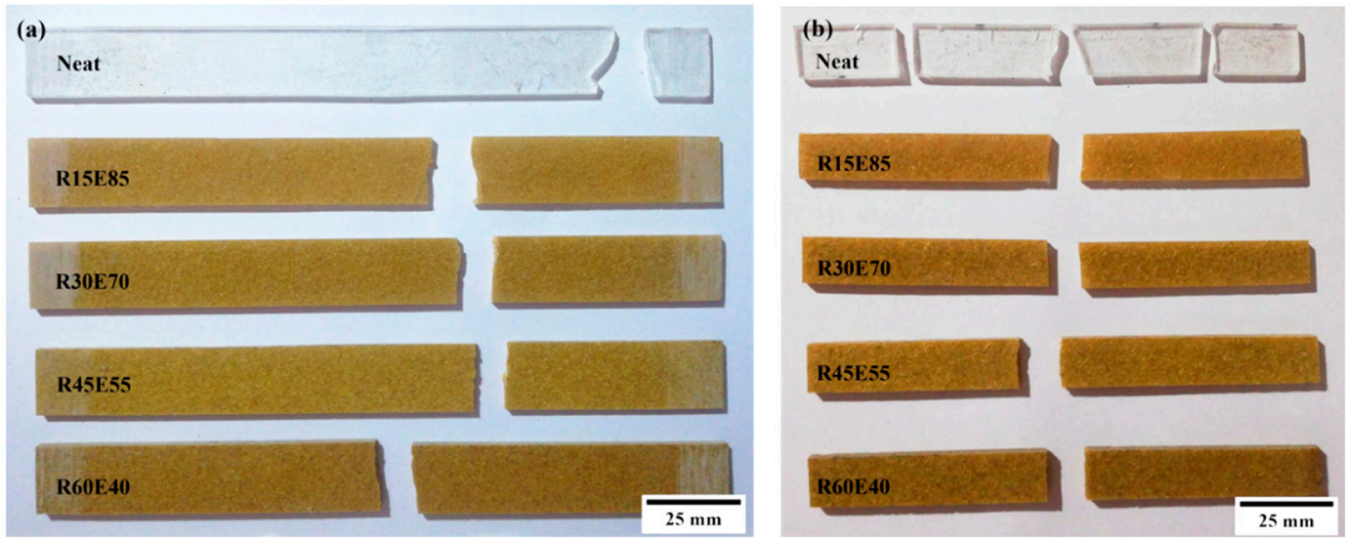

Figure 12. Fractured test samples subjected to (a) tensile (b) flexural test.
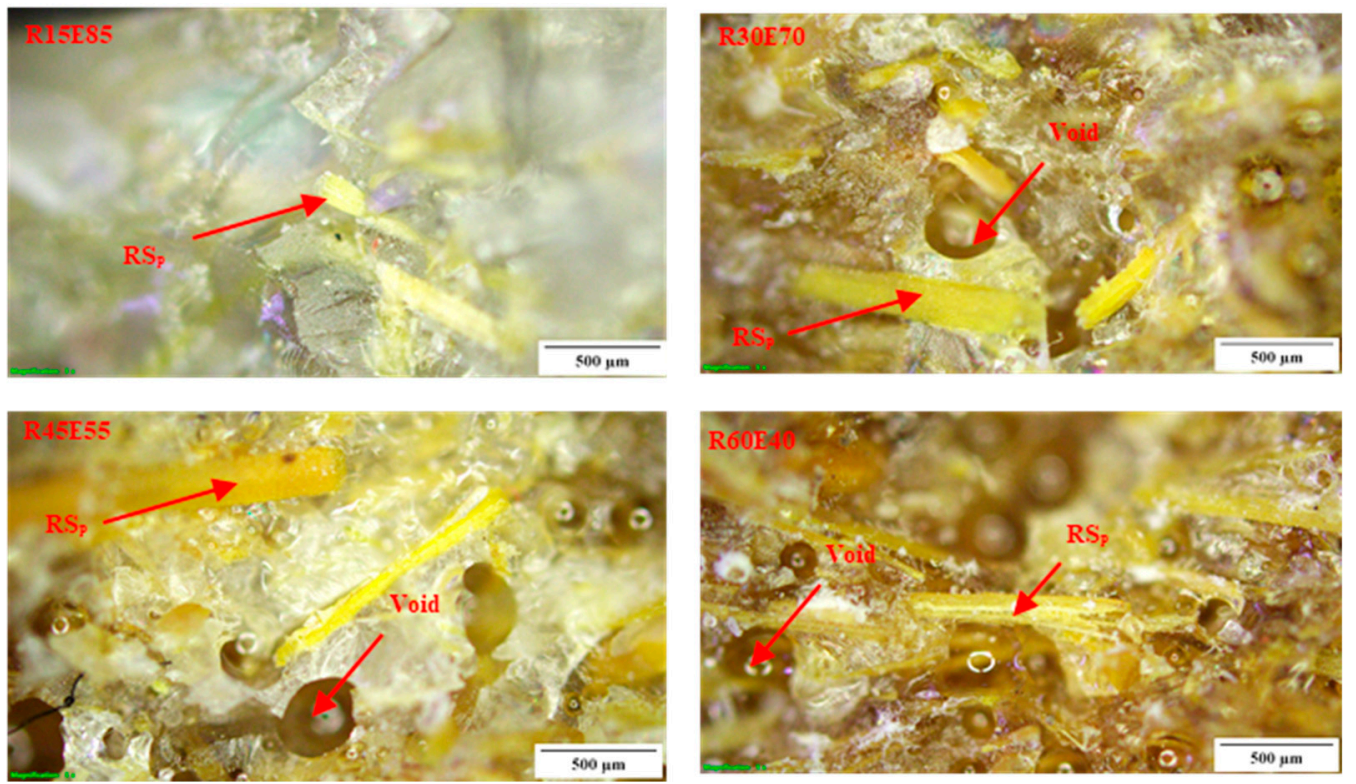

Figure 13. Tensile load-fractured surfaces of test samples.

\subsection{Liquid Absorption Study}

The test samples were subjected to the WA test to investigate their water-resistant properties. The test samples were immersed in normal water for $696 \mathrm{~h}$ under standard laboratory conditions. Figure 15 shows the WA rate of different test samples. It was observed that the neat epoxy showed almost negligible WA $(<0.05 \%)$ during the soaking period. Although epoxy material is water-resistant, a very small amount of water was absorbed by the surface voids present in the neat epoxy test sample. Further, it was observed that there was a considerable amount of WA by the test samples with RS reinforcement. The WA rate appeared to increase with higher RS content, and up to RS $\mathrm{V}_{\mathrm{F}}: 0.45$, the WA rate was less than $7.8 \%$, whereas the R60E40 composite showed the highest WA rate of $14.36 \%$. In the initial $72 \mathrm{~h}$ of soaking, the WA rate for all the test samples rapidly increased linearly, and thereafter, the absorption rate decreased and showed an almost constant trend. This was due to the exposure of the RS surface, which is hydrophilic in nature, and the 
voids present in the surface of the test sample also influenced the moisture uptake $[52,53]$. After the test sample completely absorbed the water content due to continuous soaking, a saturation point for WA was reached, beyond which the WA rate is marginal $[32,54]$.
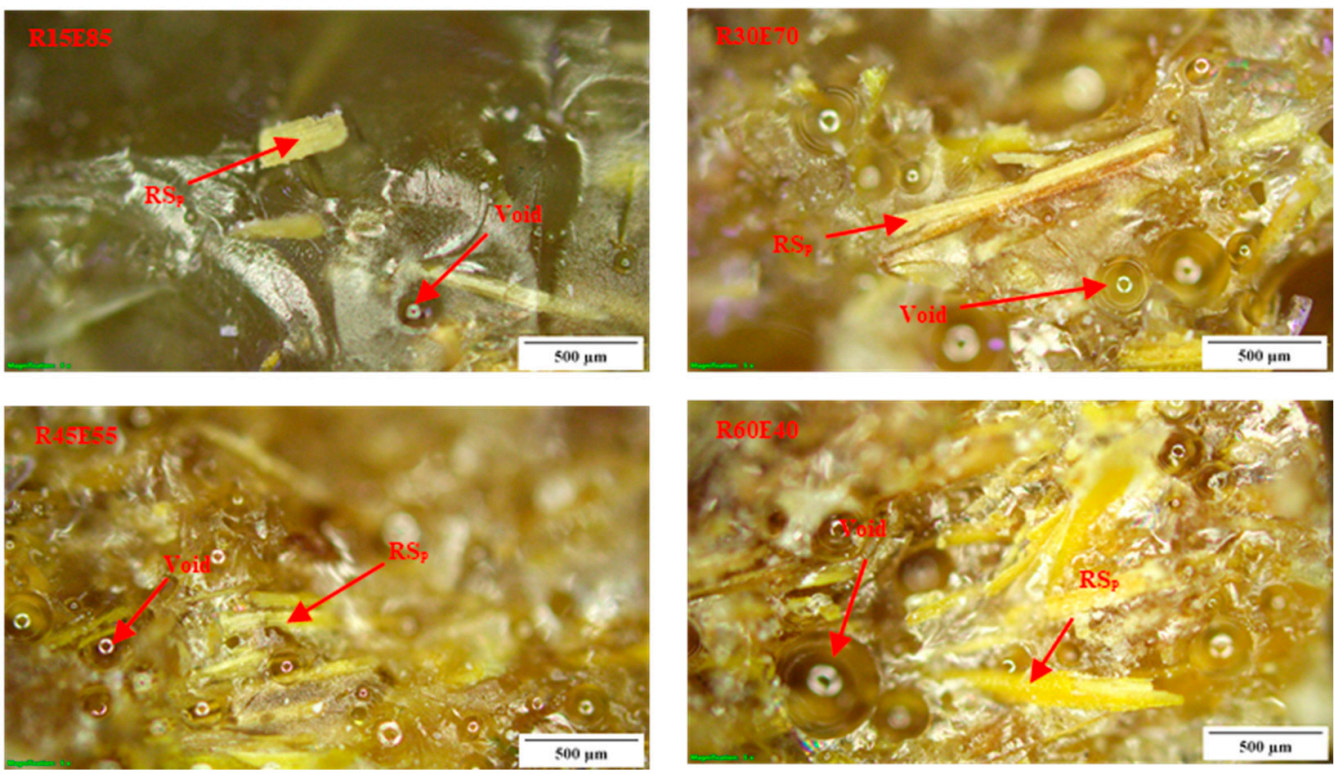

Figure 14. Flexural load-fractured surfaces.

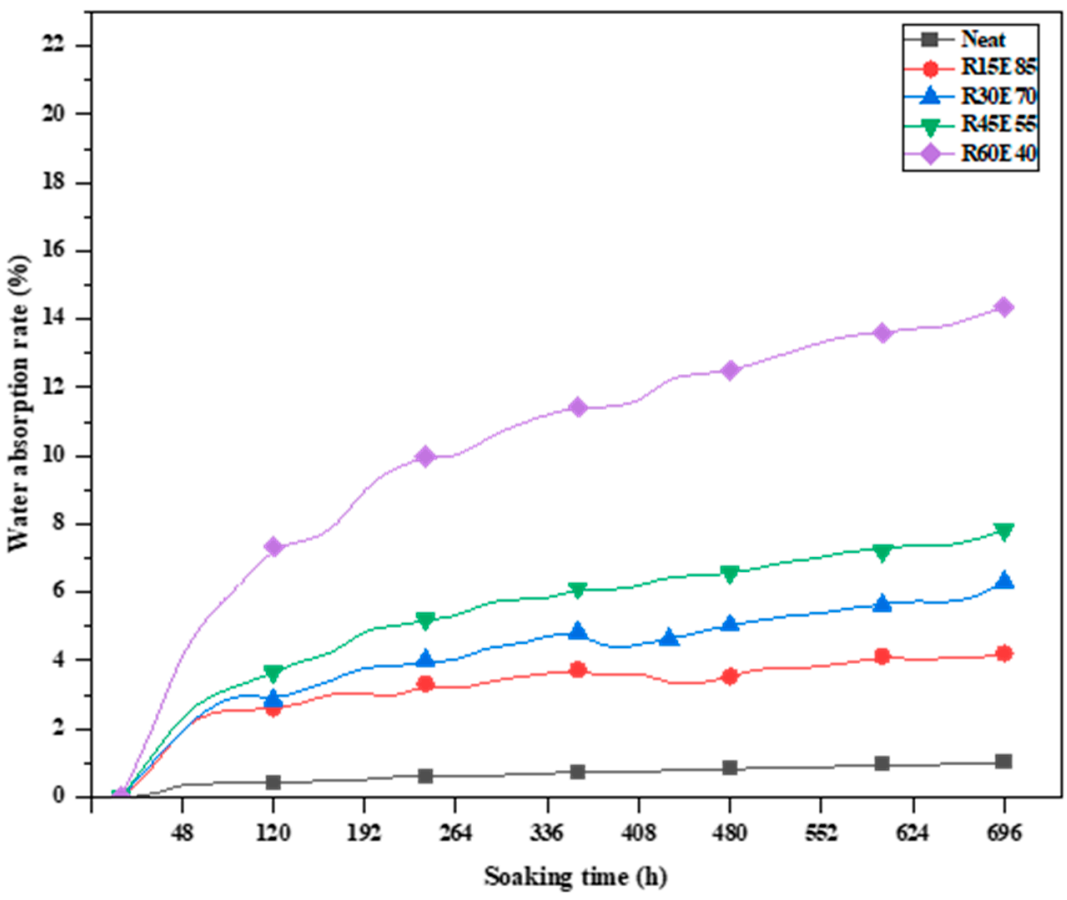

Figure 15. Water absorption rate of the $\mathrm{RS}_{\mathrm{p}}$ test samples.

All the test samples were subjected to an absorption study by immersing the test samples in KDT oil for $696 \mathrm{~h}$ under standard laboratory conditions. Figure 16 shows the KDT oil absorption rate of different test samples measured at an interval of $24 \mathrm{~h}$. The test samples initially showed a linearly increasing trend of oil absorption up to $48 \mathrm{~h}$ of the immersion period. As the immersion period increased, the rate of oil absorption gradually stabilized and reached almost a constant value. The test samples were found to completely absorb the KDT oil and reach a saturation point beyond which the increase in the oil absorption rate of the test samples was minimum. The oil absorption rate of the test 
samples was less than $2 \%$, indicating higher resistance to oil absorption. Comparative analysis of the absorption of water and KDT oil showed that the test samples were more resistant towards oil absorption than water. This is due to the higher viscosity of water compared KDT oil.

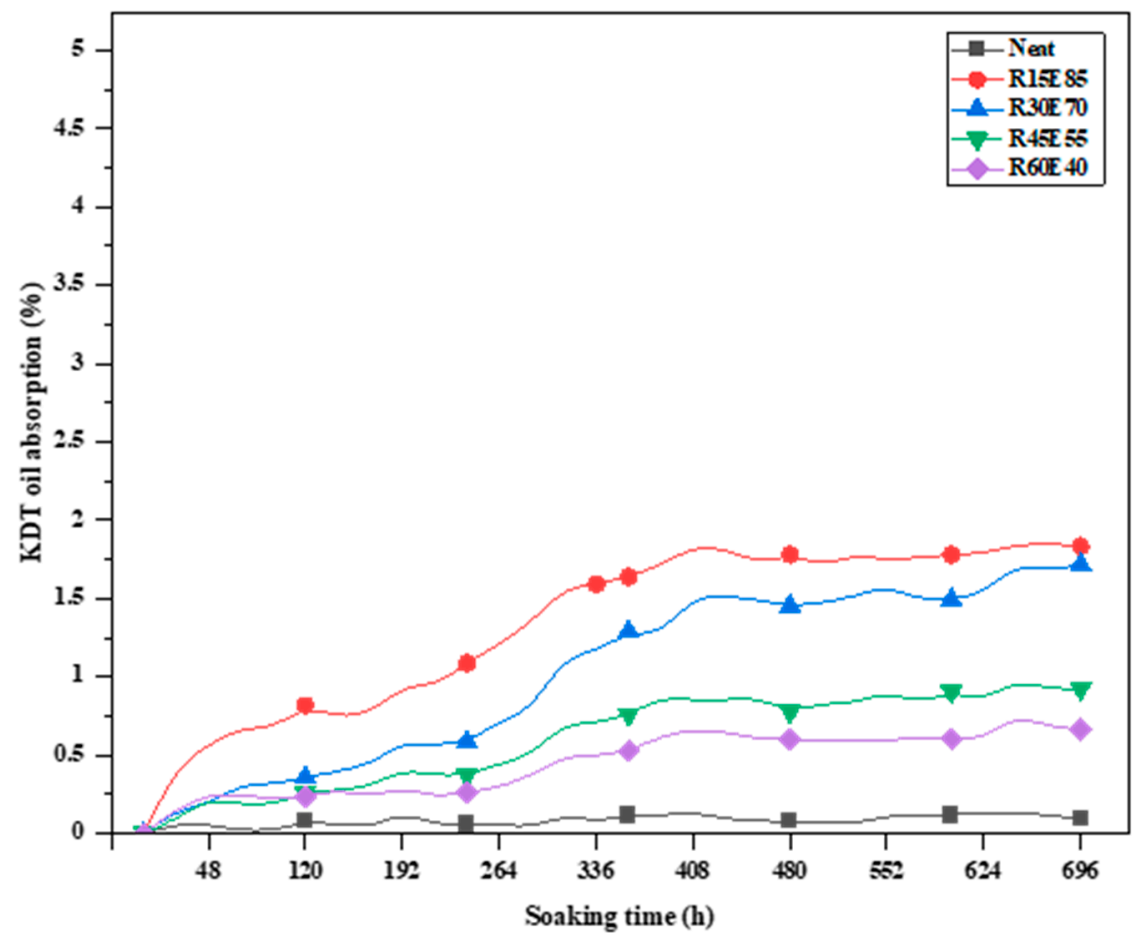

Figure 16. KDT oil absorption rate of the $\mathrm{RS}_{\mathrm{p}}$ test samples.

\subsection{Microbial Study of $R S_{p}$ Test Samples}

The test samples were investigated for two different types of bacteria, i.e., Gramnegative Escherichia coli (ATCC 25922), Pseudomonas aeruginosa (ATCC 27853) and Grampositive cocci Staphylococcus epidermidis (clinical strain). The Candida albicans (ATCC 90028) fungus was used to study the resistance of the material to fungal growth.

The bacteria from the frozen stock culture were transferred to peptone water supplemented with $5 \%$ sheep blood plates and were incubated at $37^{\circ} \mathrm{C}$ for $24 \mathrm{~h}$. The bacteria were then transferred to $50 \mathrm{~mL}$ of sterile peptone water and grown at $37^{\circ} \mathrm{C}$. The number of bacteria in the bacterial suspension was adjusted to 0.5 MacFarland standard, which is equivalent to $1 \times 10^{8}$ bacteria $/ \mathrm{mL}$. Before conducting the bacterial attachment on test samples $(50 \mathrm{~mm} \times 25 \mathrm{~mm} \times 3 \mathrm{~mm}$ ), they were cleaned by immersion in ethyl alcohol solution for $1 \mathrm{~h}$ to remove contaminants and microorganisms. Finally, test samples were washed with distilled water [55]. The immersion inoculation method was followed for the bacterial attachment and to grow the bacteria directly on the surface of the test samples [56]. The test samples were placed in a sterile container and completely covered using $20 \mathrm{~mL}$ of the bacterial suspension for $1 \mathrm{~h}$ at room temperature without shaking. The test samples were continuously immersed in the bacterial suspension and KDT oil mixture for 15 days in order evaluate the growth of bacteria on test samples as shown in Figure 17.

Finally, the test samples were removed from the bacterial suspension and were washed three times with $20 \mathrm{~mL}$ of distilled water for $10 \mathrm{~s}$ and allowed to dry under ambient conditions for $1 \mathrm{~h}$ before being sampled. Sampling was done using a swab inoculation method with the sterile swab rubbing on the test samples followed by inoculation in $5 \%$ sheep blood agar [57]. The growth of the colonies was noted. Controls used were plane glass block and KDT oil. Swabs were also collected from the surface of the bed and the sides of the bed, which was used by the patients for quality control. Figure 18 shows the microscopic image of the bacterial solution. The microbial study showed that 
the test samples were resistant against the growth of E. coli and Candida albicans bacteria, whereas Pseudomonas aeruginosa and Staphylococcal epidermidis growth was observed in the test samples. The continuous contact of KDT oil did not show microbial growth on sheep blood agar. Further, the swabs collected from the patient's bed did not influence the growth of any microorganisms on the sheep blood agar, indicating that the $\mathrm{RS}_{\mathrm{p}}$ test samples were resistant against bacterial and fungal growth.
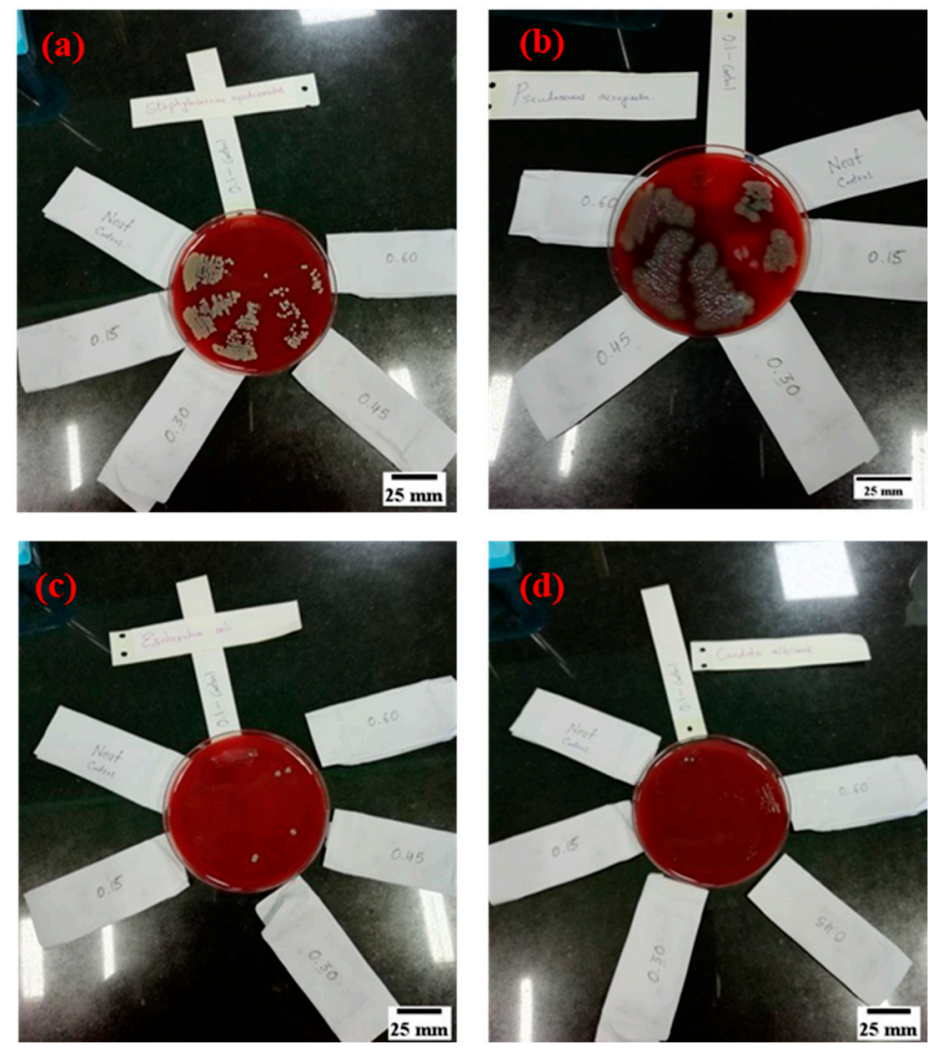

Figure 17. Test samples immersed in bacterial suspension with (a) Staphylococcus epidermidis (b) Pseudomonas aeruginosa (c) Escherichia coli (d) Candida albicans.

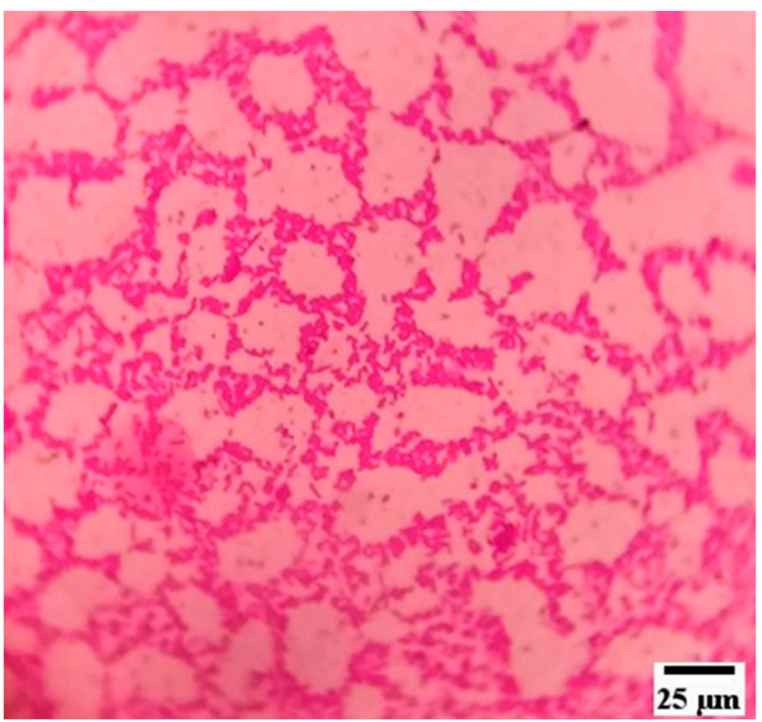

Figure 18. Microscopic image of the bacterial solution (Mag: 1000×). 


\section{Conclusions}

In the present work, $\mathrm{RS}_{\mathrm{p}}$-reinforced epoxy composite were investigated for their mechanical and liquid absorption properties to determine the effect of $\mathrm{RS}_{\mathrm{p}}$ reinforcement. The scope of the present investigation is limited to the material characterization of the mechanical and liquid absorption properties of the RS/Epoxy composite developed using untreated rice straw. There is well-established evidence which shows that the tensile and compressive properties of the untreated fibers are enhanced by the chemical treatment of the fiber. Further, the chemical treatment affects the hydrophilic nature of the fibers, which reduces the moisture absorption of the composite materials. The chemical treatment of the rice straw reduces the straw size, and the process incurs a cost. With the aim of developing cost-effective materials with fewer processing stages for using rice straw after harvesting, the present work is aimed at characterization of the properties of untreated RS/Epoxy composite. The use of RSp reinforcement considerably reduce the quantity of polymer used in making the ayurvedic treatment table and hence provides an eco-friendly solution for this application. Based on the experimental results, the following conclusions are drawn.

- The composites with $\mathrm{RS}_{\mathrm{p}}$ volume of $15 \%$ and $45 \%$ had the highest $\sigma_{T}(17.53 \mathrm{MPa})$ and $\sigma_{T}(43.24 \mathrm{MPa})$, respectively. The addition of $\mathrm{RS}_{\mathrm{p}}$ at $60 \%$ reduced the density by $54.59 \%$, hardness by $15.63 \%$, tensile strength by $51.78 \%$, and flexural strength by $63.04 \%$ compared to properties of the neat epoxy material.

- The tensile and flexural test failed specimens showed brittle fracture behavior, and the failures were observed to occur prominently near the locations of voids. Interestingly, fiber pull-outs were not found on the fractured surface. The fiber was split at the location of the crack, and the split fibers were intact with the matrix.

- The $\mathrm{RS}_{\mathrm{p}}$ composite was resistant to the exposure of water and KDT oil. Soaking of test materials for up to $696 \mathrm{~h}$ in KDT oil showed $<2 \%$ absorption. In addition, the test samples also showed the absence of microbial growth under the exposure of water and KDT treatment oil, indicating the suitability of the material for making ayurvedic treatment tables and accessories.

Author Contributions: Conceptualization, D.D., S.A.H. and K.R.H.; methodology, D.D., S.A.H. and K.R.H.; investigation, A.S.M. and S.K.L. data curation, A.S.M. and S.K.L.; writing-original draft preparation, A.S.M.; writing-D.D.; visualization, D.D. and S.A.H.; supervision, D.D. All authors have read and agreed to the published version of the manuscript.

Funding: The APC was funded by Manipal Academy of Higher Education, Manipal 576104, India.

Institutional Review Board Statement: Not applicable.

Informed Consent Statement: Not applicable.

Data Availability Statement: Data sharing is not applicable.

Conflicts of Interest: The authors declare no conflict of interest.

\section{References}

1. Shiv, K.L.; Jat, H.S.; Arvind, K.Y.; Sidhu, H.S.; Jat, M.L.; Madhu, C.; Jyotsna, K.P.; Sharma, P.C. Burning issues of paddy residue management in north-west states of India. Renew. Sustain. Energy Rev. 2018, 81, 693-706. [CrossRef]

2. Abdurrahman, M.I.; Chaki, S.; Saini, G. Stubble burning: Effects on health \& environment, regulations and management practices. Environ. Adv. 2020, 2, 100011. [CrossRef]

3. Asdrubali, F.; D'Alessandro, F.; Schiavoni, S. A review of unconventional sustainable building insulation materials. Sustain. Mater. Technol. 2015, 4, 1-17. [CrossRef]

4. Binici, H.; Eken, M.; Dolaz, M.; Aksogan, O. An environmentally friendly thermal insulation material from sunflower stalk, textile waste and stubble fibres. Constr. Build. Mater. 2014, 51, 24-33. [CrossRef]

5. Binici, H.; Gemci, R.; Kucukonder, A.; Solak, H.H. Investigating sound insulation, thermal conductivity and radioactivity of chipboards produced with cotton waste, fly ash and barite. Constr. Build. Mater. 2012, 30, 826-832. [CrossRef]

6. Binici, H.; Gemci, R.; Aksogan, O.; Kaplan, H. Insulation properties of bricks made with cotton and textile ash wastes. Int. J. Mater. Res. 2010, 101, 894-899. [CrossRef] 
7. El, H.R.; Khalaf, Y.; Lacoste, C.; Nakhl, M.; Lacroix, P. A flame retarded chitosan binder for insulating miscanthus/recycled textile fibers reinforced bio composites. J. Appl. Polym. Sci. 2019, 136, 47306. [CrossRef]

8. Hassanin, A.H.; Candan, Z.; Demirkir, C.; Hamouda, T. Thermal insulation properties of hybrid textile reinforced biocomposites from food packaging waste. J. Ind. Text. 2016, 47, 1024-1037. [CrossRef]

9. Ingrao, C.; Lo Giudice, A.; Tricase, C.; Rana, R.; Mbohwa, C.; Siracusa, V. Recycled PET fibre-based panels for building thermal insulation: Environmental impact and improvement potential assessment for a greener production. Sci. Total Environ. 2014, 493, 914-929. [CrossRef]

10. Lacoste, C.; El Hage, R.; Bergeret, A.; Corn, S.; Lacroix, P. Sodium alginate adhesives as binders in wood fibers/textile waste fibers bio composites for building insulation. Carbohydr. Polym. 2018, 184, 1-8. [CrossRef]

11. Zen, L.D.; Ocacia, G.; Sadhu, D.P. Prospect of an environmentally balanced energy system from rice husk and wind. Renew. Energy 1993, 3, 885-889.

12. Lin, Z. Reduction of energy consumption by enhancing the thermal resistance of cold storage building. Energy Resour. Environ. 1982, 1982, 413-424. [CrossRef]

13. Ismail, M.R.; Yassen, A.A.M.; Afify, M.S. Mechanical properties of rice straw fiber-reinforced polymer composites. Fibers Polym. 2011, 12, 648-656. [CrossRef]

14. Saidah, A.; Susilowati, S.E.; Nofendri, Y. Effect of fiber loading and alkali treatment on rice straw fiber reinforced composite for automotive bumper beam application. Int. J. Adv. Sci. Eng. Inf. Technol. 2019, 9, 1865-1870. [CrossRef]

15. Yu, W.; Dong, L.; Lei, W.; Zhou, Y.; Pu, Y.; Zhang, X. Effects of rice straw powder (RSP) size and pretreatment on properties of FDM 3D-printed RSP/Poly (lactic acid) bio composites. Molecules 2021, 26, 3234. [CrossRef]

16. Mahesh, M.; Bejagam, N.R.; Tirumala, K. Evaluation of mechanical properties of rice straw fibre polypropylene composites. SSRG Int. J. Mech. Eng. (SSRG-IJME)-Spec. Issue ICETST 2018, 1, 10-14.

17. Mohammadi, H.; Mirmehdi, S. Rice straw/thermoplastic composite: Effect of filler loading, polymer type and moisture absorption on the performance. Cerne 2016, 22, 449-456. [CrossRef]

18. Mutlu, I. Investigation of tribological properties of brake pads by using rice straw and rice husk dust. J. Appl. Sci. 2009, 9, 377-381. [CrossRef]

19. Nasir, R.M. Water-lubricated pin-on-disc tests with natural fibre reinforced matrix. J. Mech. Eng. 2014, 11, 41-51.

20. Neeraj, R.; Prakash, C.G.; Nisha, R. Rice husk as a fibre in composites: A review. J. Mech. Behav. Mater. 2020, 29, 147-162.

21. Patwardhan, B.; Warude, D.; Pushpangadan, P.; Bhatt, N. Ayurveda and traditional Chinese medicine: A comparative overview. Evid. Complem. Altern. Med. 2005, 2, 465-473. [CrossRef] [PubMed]

22. Soliman, S.; Ali-Eldin, S.M.; Abd, M.M.; Waleed, S.A. Study of Hybridization Effect of New Developed Rice Straw mat/ Glass Fiber Reinforced Polyester Composite. J. Nat. Fibers 2021, 18, 1194-1206. [CrossRef]

23. Witt, C.M.; Michalsen, A.; Roll, S.; Morandi, A.; Gupta, S.; Rosenberg, M.; Kronpa, L.; Stapelfeldt, E.; Hissar, S.; Müller, M.; et al Comparative effectiveness of a complex Ayurvedic treatment and conventional standard care in osteoarthritis of the knee-study protocol for a randomized controlled trial. Trials 2013, 14, 1-10. [CrossRef] [PubMed]

24. Chauhan, A.; Semwal, D.K.; Mishra, S.P.; Semwal, R.B. Ayurvedic research and methodology: Present status and future strategies Ayu 2015, 36, 364.

25. Dinesh, S.; Gopesh, M.; Rajendra, G. Ayurveda abhyanga (massage) procedure-A review. World J. Pharm. Res. 2020, 9, 16-28.

26. Sharma, M.K.; Chaturvedi, S.K. A clinical evaluation of panchavalkala-A review. Unique J. Ayurvedic Herb. Med. 2014,2 , 6-9.

27. Mallya, S.; Suchitra, P.; Vishwanatha, U.; Sunil, K. Anatomical atlas of Panchavalkala-effective healing five bark drugs in gynaecological disorders. J. Ayurvedic Herb. Med. 2018, 4, 6-13.

28. Krishna, S.; Dinesh, K.S.; Nazeema, P.K. Globalizing ayurveda-opportunities and challenges. Int. J. Health Sci. Res. 2020, 10, 55-68

29. Atluri, R.; Prasad, V.K.; Mohana, R. Experimental Investigations of Mechanical proper- ties of Golden cane fiber reinforced Polyester Composites. Int. J. Polym. Anal. Charact. 2013, 18, 30-39. [CrossRef]

30. Sakthivei, M.; Ramesh, S. Mechanical Properties of the natural fibre (Banana, Coir, Sisal) Polymer Composites. Sci. Park 2013, 1 , $1-6$.

31. Azlina, N.; Jawaid, M.; Syams, E.; Abdul, S.; Yamani, K. Tensile, physical and morphological properties of oil palm empty fruit bunch/sugarcane bagasse fibre reinforced phenolic hybrid composites. Integr. Med. Res. 2019, 8, 3466-3474. [CrossRef]

32. Mahesha, G.T.; Satish, S.B.; Vijaya, K.M.; Bhat, K.S. Preparation of Unidirectional Grewia Serrulata Fiber-Reinforced Polyester Composites and Evaluation of Tensile and Flexural Properties. J. Nat. Fibers 2016, 13, 547-554. [CrossRef]

33. Sydow, Z.; Sydow, M.; Wojciechowski, L.; Bienczak, K. Tribological Performance of Composites Reinforced with the Agricultural, Industrial and Post-Consumer Wastes: A Review. Materials 2021, 14, 1863. [CrossRef]

34. Shenoy, B.S.; Mahesha, G.T.; Kini, M.V.; Padmaraj, N.H. Effect of chemical treatments on hardness and toughness properties of grewia serrulata reinforced polymer composites. J. Mech. Eng. Res. Dev. 2019, 42, 228-230. [CrossRef]

35. de Oliveira Filho, G.C.; de Sousa Mota, R.C.; da Conceicao, A.C.R.; Leao, M.A.; de Araujo Filho, O.O. Effects of hybridization on the mechanical properties of composites reinforced by piassava fibers tissue. Compos. Part B Eng. 2019, 162, 73-79. [CrossRef]

36. Wang, L.; He, C. Characterization of rice husk fiber-reinforced polyvinyl chloride composites under accelerated simulated soil conditions. Int. J. Polym. Sci. 2019, 2019, 1-10. [CrossRef]

37. Guna, V.; Manikandan, I.; Muzamil, H.R. Groundnut shell/rice husk agro-waste reinforced polypropylene hybrid biocomposites. J. Build. Eng. 2020, 27, 100991. [CrossRef] 
38. Radzi, A.M.; Sapuan, S.M.; Jawaid, M.; Mansor, M.R. Water absorption, thickness swelling and thermal properties of roselle/sugar palm fibre reinforced thermoplastic polyurethane hybrid composites. Integr. Med. Res. 2019, 8, 3988-3994. [CrossRef]

39. Wang, S.; Li, H.; Zou, S.; Zhang, G. Experimental research on a feasible rice husk/geopolymer foam building insulation material. Energy Build. 2020, 226, 110358. [CrossRef]

40. Li, F.; Hu, H.; Yao, R.; Wang, H.; Li, M. Structure and saccharification of rice straw pretreated with microwave-assisted dilute lye. Ind. Eng. Chem. Res. 2012, 51, 6270-6274. [CrossRef]

41. Anala, R.; Nambisan, P. Study of morphology and chemical composition of phytoliths on the surface of paddy straw. Paddy Water Environ. 2015, 13, 521-527. [CrossRef]

42. Nguyen, M.N.; Than, T.N. Applied Geochemistry Arsenic in rice straw phytoliths: Encapsulation and release properties. Appl. Geochem. 2021, 127, 104907. [CrossRef]

43. Shuhaida, H.; Venkatesh, B.; Moh, S.T. Performance of AFEX ${ }^{\mathrm{TM}}$ pretreated rice straw as source of fermentable sugars: The influence of particle size. Biotechnol. Biofuels 2013, 6, 1-17.

44. Kaur, K.; Phutela, U.G. Morphological and structural changes in paddy straw influenced by alkali and microbial pretreatment. Detritus 2018, 3, 30-36. [CrossRef]

45. Mehdikhani, M.; Larissa, G.; Ignaas, V.; Stepan, V.L. Voids in fiber-reinforced polymer composites: A review on their formation, characteristics, and effects on mechanical performance. J. Compos. Mat. 2019, 53, 1579-1669. [CrossRef]

46. Li, Y.; Li, Q.; Ma, H. The voids formation mechanisms and their effects on the mechanical properties of flax fiber reinforced epoxy composites. Compos. Part A Appl. Sci. Manuf. 2015, 72, 40-48. [CrossRef]

47. Sandeep, K.; Krishan, K.S.M.; Brijesh, G.; Vinay, K.P. Synergy of rice-husk filler on physico-mechanical and tribological properties of hybrid Bauhinia-vahlii/sisal particles reinforced epoxy. J. Mater. Res. Technol. 2019, 8, 2070-2082.

48. Zafar, M.F.; Siddiqui, M. Preparation and characterization of natural fiber filled polystyrene composite using in-situ polymerisation technique. Adv. Mater. Processing Technol. 2020, 6, 1-11. [CrossRef]

49. Saba, N.; Othman, Y.A.; Zeyad, A.; Jawaid, M.; Waheedullah, G. Date palm reinforced epoxy composites: Tensile, impact and morphological properties. J. Mater. Res. Technol. 2019, 8, 3959-3969. [CrossRef]

50. Zou, Y.; Huda, S.Y. Lightweight composites from long wheat straw and polypropylene web. Bioresour. Technol. 2010, 101, 2026-2033. [CrossRef]

51. Kilinc, A.C.; Atagur, M.; Ozdemir, O.; Sen, I.; Kucukdogan, N.; Sever, K.; Seydibeyoglu, O.; Sarikanat, M.; Seki, Y. Manufacturing and characterization of vine stem reinforced high density polyethylene composites. Compos. Part B Eng. 2016, 91, 267-274. [CrossRef]

52. Yussuf, A.A.; Massoumi, I.; Hassan, A. Comparison of polylactic Acid/Kenaf and polylactic Acid/Rise husk composites: The influence of the natural particles on the mechanical, thermal and biodegradability properties. J. Poly. Environ. 2010, 18, 422-429. [CrossRef]

53. Pandian, A.; Manikandan, V.; Winowlin, J.T.; Marimuthu, U. Effect of moisture absorption behavior on mechanical properties of basalt fibre reinforced polymer matrix composite. J. Compos. 2014, 2014, 1-8. [CrossRef]

54. Zafar, M.F.; Siddiqui, M.A. Effect of filler loading and size on the mechanical and morphological behaviour of natural fibrereinforced polystyrene composites. Adv. Mater. Process. Technol. 2020, 7, 1-13. [CrossRef]

55. Parizzi, S.Q.F.; Andrade, N.J.D.; Silva, C.A.D.S.; Soares, N.D.F.F.; Silva, E.A.M.D. Bacterial adherence to different inert surfaces evaluated by epifluorescence microscopy and plate count method. Braz. Arch. Biol. Technol. 2004, 47, 77-83. [CrossRef]

56. Mann, E.E.; Manna, D.; Mettetal, M.R.; May, R.M.; Dannemiller, E.M.; Chung, K.K.; Brennan, A.B.; Reddy, S.T. Surface micropattern limits bacterial contamination. Antimicrob. Resist. Infect. Control 2014, 3, 1-9. [CrossRef]

57. Perez-Gavilan, A.; de Castro, J.V.; Arana, A.; Merino, S.; Retolaza, A.; Alves, S.A.; Francone, A.; Kehagias, N.; Sotomayor-Torres, C.M.; Cocina, D.; et al. Antibacterial activity testing methods for hydrophobic patterned surfaces. Sci. Rep. 2021, 11, 1-10. [CrossRef] 